\title{
IMPLEMENTASI PROTOKOL S/MIME PADA LAYANAN E-MAIL PENINGKATAN JAMINAN KEAMANAN SECARA ONLINE PADA KANTOR PT. TAMMAR FRASTI
}

\author{
Nahot Frastian ${ }^{1}$ \\ Program Studi Informatika, Universitas Indraprasta PGRI ${ }^{1}$ \\ nahotfrastian@gmail.com ${ }^{1}$
}

\begin{abstract}
ABSTRAK
Implementasi teknologi sistem informasi memberikan dampak dalam segala aspek kehidupan manusia, yaitu cara berkomunikasi manusia yang awalnya bersifat konvensional menjadi digital. Email merupakan layanan yang disediakan sistem teknologi informasi sebagai sarana untuk bertransaksi informasi di dunia digital. Berkomunikasi menggunakan e-mail memiliki banyak kelebihan namun di sisi lain rentan terhadap kegiatan digital attacker, seperti penyadapan. Security adalah kunci untuk pengamanan informasi yang dibawa oleh e-mail. PT. TAMMAR FRASTI merupakan organisasi yang bergerak di bidang bisnis yang menangani infrastruktur Teknologi Informasi di kalangan perusahaan swasta, yang mana kesehariannya informasi rahasia ditransaksikan menggunakan e-mail online. S/MIME merupakan salah satu alternatif pengamanan yang dapat diimplementasikan pada e-mail. Hasil akhir dari penelitan ini berupa rancangan implementasi protokol S/MIME pada layanan e-mail bagi PT. TAMMAR FRASTI yang menerapkan teknik kriptografi berupa tanda tangan digital dan/atau enkripsi yang terbukti dapat memenuhi aspek keamanan informasi. Dengan mengimplementasikan S/MIME, aspek information security seperti confidentiality, integrity, authentication dan nonrepudiation yang diharapkan oleh PT. TAMMAR FRASTI menjadi sukses.
\end{abstract}

Kata Kunci : Implementasi, digital attacker, e- security, S/MIME mail, information security.

\begin{abstract}
Implementation of information system technology has been changing all aspects of human life, such as the human's way of communication that is initially conventional into digital way. E-mail is a service provided by information technology system as a means to exchange information digitally. Even though communicating using e-mail has many advantages, it is vulnerable to digital attackers, such as tapping. Security is the key to securing information contained in e-mail. PT. TAMMAR FRASTI is a business organization that deals with Information Technology infrastructure among private companies that exchange their daily confidential information using e-mail online. S/MIME is one of the alternative security that can be implemented in e-mail. The final result of this research is the design of S/MIME protocol implementation in e-mail service for PT. TAMMAR FRASTI applying cryptographic techniques in the form of digital signatures and / or encryption proven to meet the aspects of information security. By implementing S/MIME, information security aspects such as confidentiality, integrity, authentication and non-repudiation expected by PT. TAMMAR FRASTI may be successfully realized.
\end{abstract}

Keywords : Implementation, digital attacker, e-security, S / MIME mail, information security.

\section{A. Latar Belakang}

Perkembangan Teknologi Informasi digital semakin pesat setelah munculnya internet. Internet memberikan banyak layanan yang memungkinkan manusia saling bertukar informasi tanpa mengenal jarak dan waktu. Pengguna internet di seluruh dunia sampai dengan akhir tahun 2011 seperti yang tercatat dalam survei Internet World Stats pada internetworldstats.com mencapai 2.267.233.742 pengguna, dengan statistik tertinggi pengguna dari Asia mencapai $44,8 \%$ [1].

Salah satu fasilitas internet yang paling banyak digunakan di dunia khususnya di Indonesia adalah e-mail online, karena 
dengan adanya e-mail para pengguna dapat saling bertukar informasi. Bahkan tercatat dari hasil riset Ipsos bahwa 9 dari10 (91\%) pengguna internet di Indonesia menggunakan e-mail online untuk kirim/terima (transaksi) informasi [2]. Meskipun menjadi sarana transaksi informasi yang handal dan banyak digunakan,mekanisme pengiriman e-mail umumnya dilakukan melalui internet yang merupakan jalur publik sehingga memungkinkan terjadinya serangan oleh digital attacker seperti penyadapan dan modifikasi informasi. Proses transaksi informasi melalui e-mail pada dasarnya menggunakan protokol plaintext, sehingga jika terjadi penyadapan akan menyebabkan kebocoran informasi, dengan kata lain mengancam kerahasiaan informasi dari email tersebut. Selain terkendala pada aspek kerahasiaan informasi, penerima e-mail tidak dapat memastikan keaslian sumber pesan, untuk mengetahui bahwa e-mail tersebut memang berasal dari orang yang diajak berkomunikasi. Karena e-mail tidak memiliki layanan untuk memverifikasi pengirim e-mail, maka pengirim pada suatu waktu dapat menyangkal bahwa dirinya tidak pernah mengirim e-mail tersebut. Kedua kendala tersebut dapat diatasi dengan teknik kriptografi berbasis sertifikat digital kunci publik (public key) atau yang dikenal sebagai protokol S/MIME karena terdapat dua proses yang dilakukan yaitu proses enkripsi sebagai solusi dari ancaman kerahasiaan informasi dan proses digital signature sebagai solusi untuk melakukan verifikasi terhadap pengirim e-mail.

Prinsip kerja S/MIME adalah mengirimkan informasi yang ditandatangani menggunakan private key pengirim dan kemudian mengenkripsinya menggunakan public key penerima, selanjutnya informasi tersebut dikirim ke penerima secara point to point melalui mail server, setelahnya pihak penerima akan mendekripsinya menggunakan private key penerima dan diotentikasi keaslian pengirimnya dengan public key pengirim. Proses digital signature dan enkripsi hanya terjadi antar user yang menggunakan e-mail S/MIME, tidak terjadi pada mail server. Selain itu user yang tidak terdaftar sebagai grup terbatas tidak akan dapat melakukan komunikasi secure karena tidak memiliki sertifikat digital. PT. TAMMAR FRASTI merupakan organisasi bisnis yang menangani infrastruktur TI di kalangan instansi pemerintah dan swasta. Dalam melakukan proses komunikasi dan koordinasi, pimpinan dan karyawan PT. TAMMAR FRASTI menggunakan layanan e-mail untuk saling bertransaksi informasi. Data atau informasi yang biasanya dikomunikasikan bersifat terbatas dan rahasia seperti proyek perusahaan, nama pelanggan, jenis proyek, nama proyek, dana proyek, pihak yang terlibat dalam proyek, dan lain-lain. Informasi yang demikian tentunya akan berdampak buruk apabila jatuh ke tangan pihak yang tidak berhak, contohnya pihak pesaing bisnis.

Berangkat dari uraian di atas, peneliti menawarkan alternatif solusi berupa rancangan implementasi protokol S/MIME pada layanan e-mail untuk PT. TAMMAR FRASTI, yang mana bila rancangan tersebut diterapkan oleh PT. TAMMAR FRASTI maka peningkatan keamanan dalam bertransaksi informasi secara online akan terjamin.

\section{B. Masalah Penelitian Identifikasi Masalah}

Berdasarkan latar belakang penelitian yang telah diuraikan, maka dapat di identifikasi permasalahan penelitian sebagai berikut:

1) PT. TAMMAR FRASTI melakukan transaksi informasi yang bersifat rahasia danterbatas menggunakan layanan e-mail online melalui jaringan publik (internet).

2) Internet rentan terhadap serangan penyadapan dan modifikasi pesan yang 
dilakukan oleh digital attacker.

3) Dikarenakan PT. TAMMAR FRASTI mengirimkan e-mail melalui jaringan internet, maka rentan terhadap kebocoran informasi yang pada akhirnya dapat menimbulkan dampak buruk bagi perusahaan.

4) PT. TAMMAR FRASTI memerlukan alternatif solusi berupa rancangan pemanfaatan S/MIME yang dapat menjamin terpenuhinya aspek-aspek keamanan informasi khususnya e-mail yang meliputi confidentiality, integrity, authentication dan non-repudiation.

\section{Batasan Masalah}

Dengan adanya keterbatasan waktu dan sumber daya, maka penelitian Ini hanya membahas rancangan implementasi S/MIME pada layanan e-mail untuk PT. TAMMAR FRASTI, simulasi dan pengujian implementasi dari rancangan yang dibuat, serta perbandinganan keamanan dari hasil simulasi sebelum dan sesudah implementasi rancangan tersebut.

\section{Rumusan Masalah}

Dari identifikasi dan pembatasan masalah di atas, maka rumusan masalah penelitian ini dituangkan dalam bentuk pertanyaan penelitian sebagai berikut:

1) Solusi apakah yang dapat diterapkan untuk menjamin keamanan transaksi informasi berbasis layanan e-mail online bagi PT. TAMMAR FRASTI?

2) Bagaimanakah implementasi protokol S/MIME pada layanan e-mail bagi PT. TAMMAR FRASTI?

3) Bagaimanakah perbandingan keamanan dari hasil simulasi sebelum dan sesudah implementasi rancangan tersebut?

\section{Tujuan dan Manfaat Penelitian}

Penelitian ini bertujuan:

1) Mendeskripsikan rancangan implementasi S/MIME pada layanan e-mail online PT. TAMMAR FRASTI.

2) Membuktikan aspek keamanan yang dapat terpenuhi dalam transaksi informasi menggunakan e-mail yang menerapkan S/MIME.

3) Membandingkan keamanan transaksi informasi menggunakan e-mail online antara sebelum dan sesudah menerapkan S/MIME.

Manfaat dari penelitian adalah sebagai berikut:

1) Manfaat akademis Hasil dari penelitian diharapkan dapat mengembangkan pengetahuan,menambah wawasan kepustakaan pendidikan serta dapat menjadireferensi bagi penelitian selanjutnya.

2) Manfaat praktis Hasil dari penelitian diharapkan dapat menjadi bahan masukan bagi PT. TAMMAR FRASTI yang dapat diimplementasikan untuk meningkatkan keamanan komunikasi berbasis e-mail.

\section{METODE PENELITIAN}

Dalam penelitian ini penulis memilih metode penelitian deskriptif kualitatif.

Selain menggunakan metode deskriptif kualitatif, penelitian ini juga menggunakan metode simulasi untuk membuktikan efektivitas dari hasil rancangan implementasi yang dibuat. Metode penelitian kualitatif digunakan digunakan untuk meneliti pada tempat yang alamiah, dan penelitian tidak membuat perlakuan, karena peneliti dalam mengumpulkan data bersifat emic, yaitu berdasarkan pandangan dari sumber data, bukan pandangan peneliti. Dalam penelitian kualitatif peneliti sebagai human instrument dan dengan teknik pengumpulan data participant

observation (observasi berperan serta) dan in depth overview (wawancara mendalam), maka peneliti harus berinteraksi dengan sumber data. Walaupun penelitian kualitatif tidak membuat generalisasi, bukan berarti hasil penelitian kualitatif tidak dapat diterapkan 
di tempat lain. Generalisasi dalam penelitian kualitatif disebut transferability dalam bahasa Indonesia dinamakan keteralihan. Maksudnya adalah bahwa hasil penelitian kualitatif dapat ditransferkan atau diterapkan di tempat lain, manakala kondisi tempat lain tersebut tidak jauh berbeda dengan tempat penelitian [3].

\section{Langkah Penelitian}

Tahapan penelitian dapat di deskripsikan sebagai berikut:

1. Melakukan survei awal

Langkah ini bertujuan untuk mengetahui kondisi pelaksanaan transaksi informasi melalui layanan emailonline yang dilakukan PT. TAMMAR FRASTI saat ini. Survei awal ini merupakan salah satu metode pengumpulan data. Survei awal dalam penelitian ini dilakukan dengan teknik wawancara dan observasi.

2. Melakukan studi pustaka

Penelitian ini dimulai dengan melakukan studi pustaka yang berkaitan dengan pemanfatan protokol S/MIME pada layanan e-mail. Studi pustaka dilakukandengan mempelajari konsep dasar e-mail, e-mail security, aspek keamanan jaringan komputer, kriptografi, enkripsi/dekripsi, tanda tangan digital, Public Key Infrastructure (PKI), sertifikat digital, MIME dan S/MIME.

3. Membuat rancangan implementasi

Setelah mengetahui kondisi di lapangan, langkah selanjutnya adalah membuat rancangan pemanfaatan protokol S/MIME pada layanan e-mail bagi PT. TAMMAR FRASTI.

\section{HASIL DAN PEMBAHASAN}

\section{Profil Perusahaan}

PT. TAMMAR FRASTI merupakan organisasi yang bergerak di bidang teknologi informasi khususnya menangani infrastruktur jaringan di berbagai perusahaan swasta. PT. TAMMAR
FRASTI dipimpin oleh seorang Direktur Utama. Dalam menjalankan proses bisnisnya, PT. TAMMAR FRASTI memiliki bagian yang khusus menangani core business-nya di bidang teknologi informasi, disebut Divisi IT. Dalam hal ini Divisi IT dipimpin oleh seorang Direktur IT. Berikut merupakan struktur organisasi pada lingkup Divisi IT.

\section{Infrastruktur E-mail PT. TAMMAR FRASTI}

Berdasarkan pengamatan peneliti, PT. TAMMAR FRASTI memiliki infrastruktur e-mail yang relatif memadai terlihat dari kelengkapan-kelengkapan jaringan yang digunakan, termasuk bandwidth internet yang dimiliki. Perangkat-perangkat jaringan yang dimiliki adalah router, switch, firewall, access point (AP), mail gateway dan mail server. Perangkatperangkat tersebut digunakan oleh PT. TAMMAR FRASTI untuk koneksi internet dan diantaranya menjalankan layanan email perusahaan.

\section{Klasifikasi Data/Informasi PT. TAMMAR FRASTI}

Dari diskusi yang dilakukan antara peneliti dengan Asisten Manajer TI, peneliti dapat mengklasifikasikan jenis data/informasi yang ditransaksikan melalui layanan e-mail. Klasifikasi dari jenis data/informasi yang ditransaksikan yaitu:

1. Data/informasi biasa

Adalah informasi yang bersifat umum dan semua pihak boleh mengetahui dan mempergunakannya.

2. Data/informasi rahasia

Adalah informasi yang bersifat terbatas dan tidak semua pihak berhak mengetahui dan mempergunakannya.

Data/informasi yang ditransaksikan memiliki format yang bermacam-macam jenisnya seperti teks (word, excel, power point, pdf, dll), gambar (.jpeg, .jpg, .png, bmp, .gif, dll), audio (.mp3, .wav, dll), 
video (.3gp, .flv), dsb.

\section{Proses Transaksi Data/Informasi}

Proses transaksi (kirim/terima) data/informasi yang dilakukan oleh user PT. TAMMAR FRASTI adalah menggunakan layanan e-mail. User melakukan kirim/terima e-mail melalui aplikasi e-mail client, aplikasi tersebut yaitu Mozilla Firefox.

Mekanisme kirim/terima e-mail yang terjadi antar user PT. TAMMAR FRASTI adalah sebagai berikut:

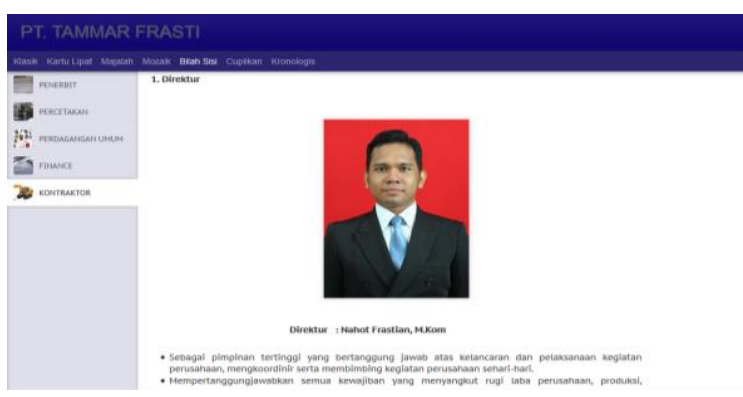

Gambar 1. Tampilan user interface pada Mozilla Firefox

1.User pada sisi pengirim menjalankan aplikasi Mozilla dan mengklik fitur tulis pesan untuk mengirimkan e-mail.

2.Untuk mengirim e-mail, user memasukkan alamat tujuan/penerima dan subjek pesan, menulis teks pesan, serta melampirkan attachment file apabila dibutuhkan, kemudian mengirimkannya.

3. E-mail yang dikirimkan tersebut akan melalui port SMTP mail server PT.TAMMAR FRASTI, kemudian mail server akan memeriksa alamat tujuan/penerima, mail server juga akan menampung dan menyimpan data/informasi dari e-mail yang dikirimkan, selanjutnya mail server PT. TAMMAR FRASTI meneruskan e-mail yang dikirim ke POP3 tujuan/penerima. Alur diagram di bawah ini untuk memperjelas mekanisme kirim/terima email antar user PT. TAMMAR FRASTI. Alur diagram di bawah ini untuk memperjelas mekanisme kirim/terima email antar user PT. TAMMAR FRASTI: Gambar IV.3.

Alur diagram kirim/terima e-mail antar user PT. TAMMAR FRASTI Pengirim Jalankan Aplikasi Mozilla Thunderbird Klik Fitur Tulis Pesan Isi Alamat Tujuan/ Penerima, Subject, Teks Pesan, Lampirkan Attachment File (jika diperlukan) Kirim Email Mail Server SMTP Pengirim Mengecek Alamat Tujuan/Penerima Menampung \& Menyimpan Data/ Informasi E-mail yang dikirimkan Meneruskan E-mail yang dikirimkan ke POP3 Penerima Penerima Jalankan Aplikasi Mozilla Thunderbird Notifikasi Inbox E-mail Membuka E-mail yang Masuk, Membaca pesan, Download Attachment (jika ada) Selesai .

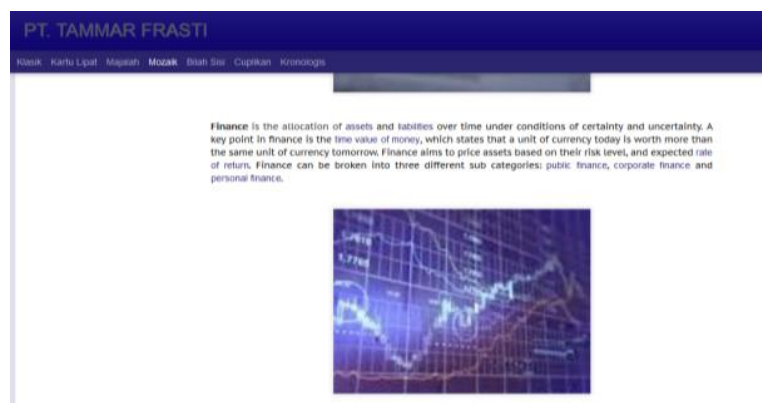

Gambar 2. Tampilan user interface pada Mozilla Firefox.

\section{Model Keamanan}

Model keamanan yang telah dilakukan oleh PT. TAMMAR FRASTI untuk mengamankaninfrastruktur e-mail sampai dengan saat ini adalah dengan memasang firewall, antivirus dan antispam yang terintegrasi pada mail server TAMMAR FRASTI.

\section{Firewall}

Firewall digunakan untuk melindungi jaringan komputer yang ada di dalam PT. TAMMAR FRASTI. Hanya paket data yang di-allow yang boleh masuk/keluar jaringan.

PT. TAMMAR FRASTI, selain itu maka akan di-block.

PT. TAMMAR FRASTI berbasis 
perangkat keras dan dipasang pada pintu gerbang (gateway) antara router dan LAN PT. TAMMAR FRASTI.

2. Antivirus

Untuk melindungi infrastruktur e-mail terhadap serangan virus, trojan, malware maupun program jahat lainnya yang masuk ke dalam sistem email maka digunakanlah antivirus yang telah terintegrasi di mail server PT.TAMMAR FRASTI.

3. Antispam

Untuk melindungi user mendapatkan email sampah maka digunakanlah anti spam yang terintegrasi di perangkat keras mail server PT.TAMMAR FRASTI.

\section{Hambatan/Kendala yang Dihadapi}

Hambatan/kendala yang dihadapi oleh PT. TAMMAR FRASTI dalam melakukan transaksi data/informasi melalui layanan e-mail yaitu belum adanya pengamanan dalam proses transaksi data/informasi antar userbaik itu user yang berada di dalam maupun di luar kantor (mobile network) PT. TAMMAR FRASTI. Resikonya adalah data/informasi yang ditransaksikan dapat mudah disadap.

\section{Pemilihan Protokol S/MIME}

Seperti yang telah dijelaskan pada latar belakang masalah, protokol S/MIME merupakan salah satu solusi alternatif yang sesuai untuk diimplementasikan pada layanan e-mail bagi PT. TAMMAR FRASTI dengan alasan sebagai berikut:

1. PT. TAMMAR FRASTI telah memiliki infrastruktur jaringan internet.

2. Tidak diperlukan biaya tambahan untuk mengimplementasikan S/MIME karena aplikasi yang dibutuhkan bersifat open source dan multiplatform OS.

3. Investasi S/MIME lebih ringan daripada pengadaan jaringan pribadi (WAN) maupunVPN.

\section{SIMPULAN}

Dari uraian yang telah dipaparkan pada bab-bab sebelumnya, maka dapat diambil kesimpulan sebagai berikut:

1. Penelitian Uraian simpulan teknologi protokol S/MIME merupakan solusi alternatif yang sesuai bagi PT. TAMMAR FRASTI untuk mengamankan layanan e-mail dalammentransaksikandata/informasi antar entitas/user, namun sampai dengan saat ini PT. TAMMAR FRASTI belum memiliki rancangan implementasi protokol S/MIME yang nantinya dapat dilaksanakan.

2. Peneliti melakukan perancangan implementasi protokol S/MIME yang sesuai dengan kebutuhan PT. TAMMAR FRASTI, meliputi topologi infrastruktur e-mail yang menerapkan protokol S/MIME serta tahapan implementasi dari rancangan tersebut. Dalam rancangan implementasi protokol S/MIME pada layanan e-mail yang peniliti usulkan, telah ditentukan bahwa rancangan tersebut tidak akan mengubah konfigurasi mail server yang saat ini sedang berjalan. Selain itu, teknologi protokol S/MIME yang diterapkan juga bersifat open source dan multiplatform OS. Saat ini PT. TAMMAR FRASTI telah memiliki infrastruktur e-mail mandiri yang nantinya dapat mengimplementasikan teknologi pengamanan e-mail menggunakan protokol S/MIME.

3. Hasil simulasi yang dilakukan oleh peneliti, didapatkan bahwa transaksi email yang menerapkan protokol S/MIME dapat sukses dilakukan. Hal ini terlihat dari berhasilnya kegiatan kirim dan terima data/informasi via email dengan mengaktifkan fitur enkripsi dan tanda tangan digital.

\section{Saran}

Penelitian yang telah dilakukan, maka beberapa hal yang disarankan adalah sebagai berikut: 
1. Implementasi protokol S/MIME ini akan direalisasikan, maka perlu adanya kebijakan dari pimpinan PT. TAMMAR FRASTI yang menjelaskan kualifikasi SDM sebagai administrator CA yang diijinkan untuk melakukan manajemen protokol S/MIME.

2. Kebijakan kualifikasi SDM, ketika rancangan implementasi protokol S/MIME ini akan direalisasikan maka hal lain yang diperlukan adalah adanya kebijakan dari pimpinan yang mengharuskan setiap entitas/user yang terlibat dalam transaksi data/informasi menggunakan S/MIME untuk merahasiakan data/informasi yang ditransaksikan. Hal ini bertujuan agar tidak terjadinya kebocoran yangdisebabkan oleh kelalaian entitas/user.

3. Penelitian lebih lanjut dari segi efisiensi dan efektifitas pada rancangan implementasi protokol S/MIME yang dibuat oleh peneliti.

\section{DAFTAR PUSTAKA}

[1] Internet World Stats. 2011. Internet Usage Statistics.

http://www.internetworldstats.com/stat s.htm. 25 Mei 2012

[2] Ipsos. 2012. Most Global Internet Users Turn to the Web for Emails $(85 \%)$ and Social Networking Sites (62\%). http://www.ipsos-na.com/. 25 Mei 2012.

[3] Sugiyono, Metode Penelitian Kuantitatif, Kualitatif dan R\&D, Jakarta: Alfabeta, 2009.

[4] C. Adams, S. Farrel, RFC 2510:Internet X.509 Public Key Infrastructure Certificate Management Protocols, California: IETF, 1999.
[5] C. Adams, and S. Lloyd, Infrastructure: Concepts, Standards, and Deployment Considerations, Indianapolis: Macmillan Technical Publishing, 2000.

[6] Banday, M. Tariq,

Parallel Systems (IJDPS): Effectiveness and Limitations of Email Security Protocols, 2011.

[7] R. Barker, Elain, etc., NIST SP 80021:Guideline for

Implementing Cryptography In the Federal Government, New York: NIST, 2005.

[8] Anonim.2008. DRM TechnologiesDRM (Part 2). 2012.

[9] Chernick, C. Michael, NIST SP 80049: Federal S/MIME V3Client Profile, New York: NIST, 2002.

[10] Cutra, Angga O., Aplikasi Pengamanan Pesan pada Mail dengan menggunakan Algoritma CAST-128, Bandung: UNIKOM,2007.

[11]Departemen Perindustrian dan Perdagangan, Naskah Akademik Rancangan Undang-Undang tentang Tanda Tangan Elektronik dan Transaksi Elektronik, Jakarta: Dirjen Perdagangan Dalam Negeri, 2001.

[12] Forouzan, Behrouz A., Cryptography and Network Security, New York: Mc Graw Hill, 2008.

[13] S. Garfinkel. 2009. Signed, Dealed and Delivered, CSO Online.2012.

[14]Gill, Sunny, etc.,International Journal of Computer Trends and Technology: E-mail Security Protocol, 2011. 